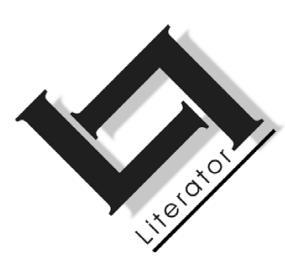

\title{
Beckett and Coetzee: alternative identities
}

\author{
N.C.T. Meihuizen \\ Department of English \\ Potchefstroom Campus \\ North-West University \\ POTCHEFSTROOM \\ E-mail: nicholas.meihuizen@nwu.ac.za
}

\section{Abstract \\ Beckett and Coetzee: alternative identities}

Coetzee's scholarly interest in Beckett, and his aesthetic interest in the same (which carries a strong measure of readily acknowledged influence), diverge in the case Coetzee presents in a recent mini-biography cum autobiography, "Samuel Beckett in Cape Town - an imaginary history" (Coetzee, 2006:74-77), where both he and Beckett are imagined as having experienced alternative pasts in South Africa. Considering this acknowledged influence, which Coetzee (1992b) mentions in an interview with David Attwell in "Doubling the point", one might assume that it followed an initial scholarly interest in Beckett (Coetzee's Ph.D. was on Beckett, and was completed years before he himself became a creative writer). However, in the case at hand this causal sequence is broken, because the doubled Coetzee, though under the spell of Beckett's prose, does not wish to do scholarly work on the doubled Beckett. What is it about Coetzee's imagined Beckett that has this effect on him? And why is it that Coetzee engages in such metafictional blurred doubling when it comes to himself and Beckett? This article attempts to shed light on the problems that surround Coetzee's crafted interaction between authors who are also (in this rather odd context) characters.

\section{Opsomming}

\section{Beckett en Coetzee: alternatiewe identiteite}

Coetzee se vakkundige belangstelling in Beckett en sy estetiese belangstelling in hom (wat geredelik erken word as ' $n$ 
sterk invloed), loop uiteen in Coetzee se onlangse kort biografie-cum-outobiografie "Samuel Beckett in Cape Town - an imaginary history" (Coetzee, 2006:74-77). Daarin word vir sowel Coetzee as Beckett verbeelde alternatiewe verledes in SuidAfrika geponeer. Aangesien Beckett 'n selferkende invloed vir Coetzee (1992b) se skeppende werk is, soos blyk uit 'n onderhoud met David Atwell in "Doubling the point", sou 'n mens kon vermoed dat dit die uitvloeisel was van 'n aanvanklike vakkundige belangstelling. (Coetzee se Ph.D. het oor Beckett gegaan en is voltooi lank voordat hy self kreatief begin skryf het.) Hierdie moontlike oorsaaklike verband word egter in die teks hier ter oorweging weerspreek, want Coetzee se dubbelganger, hoewel onder die invloed van Beckett se prosa, het geen behoefte om vakkundige werk oor die Beckett-dubbelganger te doen nie. Wat is dit omtrent Coetzee se fiktiewe Beckett wat hierdie effek op hom het? Hoekom bemoei Coetzee hom met so 'n verdoeselde metafiksionele verdubbeling van homself en Beckett? Hierdie artikel probeer lig werp op die problematiese aard van Coetzee se verbeelde interaksie tussen skrywers, wat (in hierdie redelik vreemde konteks) terselfdertyd ook karakters is.

\section{Introduction}

J.M. Coetzee (2006:74), in Samuel Beckett in Cape Town: an imaginary history, makes reference to Beckett's following letter, in which the Irish writer applies for a lectureship in Italian at the University of Cape Town. ${ }^{1}$ As in Summertime, Coetzee (2009) draws on "a matter of public record" in order to provide an objective point of reference for associated creative "fictioneering" (Kermode, 2009:10; Coetzee, 2009:225):

July 29th 1937

Dear Sir

I beg to apply for the post of lecturer in Italian in the University of Cape Town.

I enclose copies of testimonials and a brief curriculum vitae.

The following will act as referees:

1 This article is a revised version of a paper originally delivered at the International Association for the Study of Irish Literatures Conference in Oporto, 28 July-1 August 2008. 
[Three names are given, those of a solicitor, an army chaplain, and a doctor.]

Yours faithfully

Samuel Beckett [signature]

(Samuel Beckett, M.A., T.C.D.)

Had Beckett been accepted and had he accepted his acceptance, his life, speculates Coetzee, would have entered an alternative plane, and would have influenced an alternative Coetzee's intellectual life. As a professor twenty years later, and had he agreed to lend a hand with the Wednesday afternoon creative writing class, Beckett would have met a young undergraduate, John Maxwell Coetzee. His play, Waiting for Godot, its language inspired by the rough-neck slang of the Cape Flats, would have been known to the young Coetzee, who might even have seen a performance. Though the socio-politics of the time are clearly not uppermost in Coetzee's mind when he writes of the alternative Beckett in Cape Town, he is perfectly aware that Beckett disallowed his plays from being performed before segregated audiences in South Africa, that it was not until 1976 that he gave permission, and then only under the strictest condition that the play in question, Godot indeed, be performed before mixed audiences (Knowlson, 1995:637). ${ }^{3}$ The undergraduate Coetzee, having met Professor Beckett in the 1950s Cape Town, but not being interested in acquiring a "spiritual father" (Coetzee, 2006:75), would still have left South Africa, and would eventually

2 The above is a partial transcription of Beckett's original letter to the University of Cape Town, reproduced in Beckett remembering: remembering Beckett (Coetzee, 2006:76).

3 The socio-political environment of 1950s South Africa needs to be kept in mind of course, when considering Coetzee's imagined relationship with Beckett at this time. As Attwell (2008:234-235) notes: Coetzee's aesthetics (and Coetzee's present imagined relationship is of this order) are informed by the nexus of the subject in a body, history, and language. Coetzee's reference to Beckett's Godot in a 1950s South African setting bears a relation to his pronouncement in Attwell's Dagens Nyheter interview with him in 2003: "[I]n the hands of a dramatist of the sensitivity and skill of Athol Fugard, Beckett can be transplanted into South African surroundings in such a way that he seems almost native there." (Coetzee, 2003.) The nexus "body-history-language" also informs the plays of Fugard, who is, in a sense, Beckett's South African avatar. In less oblique terms, as James Knowlson shows, Beckett's presence was felt in South Africa at a time of crisis in the 1970s, when performances of Godot and Endgame were staged at the Market Theatre, The Space, and the Baxter Theatre (Knowlson, 1995:636-639). 
have gone to study in America, as the actual Coetzee did in fact do. The actual Coetzee says, however, that the alternative Coetzee would not have written a Ph.D. on the prose style of Professor Beckett, as the actual Coetzee did on the prose style of Samuel Beckett. One wonders why not. Maybe because the professor was personally known to him, and writing about him might acknowledge him as a dreaded "spiritual father". Or maybe the alternative Coetzee was not interested in a prose style inflected with the argot of the Cape Flats. The last option cannot be a reason, because both Coetzees, so to speak, feel that the matter of being influenced by Beckett's style is "another question entirely" from wanting or not wanting to write a Ph.D. on him (Coetzee, 2006:76). The reason why the alternative Coetzee would not have written a Ph.D. on Professor Beckett, but would still have been influenced by his style, is not clear from Coetzee's brief account in the alternative history. Is looking for an answer to the question, "Why would Coetzee not write a Ph.D. on Professor Beckett as opposed to Samuel Beckett?" useful in helping us understand Coetzee's quite complex relationship with Beckett, and so shed a little light on both authors? I believe that this is the case, and hope at least to be able to move towards demonstrating as much (or as little?) in what follows.

\section{Autobiography/autography}

Autography is the term used by $\mathrm{H}$. Porter Abbott "to characterize the ways in which Samuel Beckett interweaves first-person voices and issues of self-reference into his fictional narratives" (Smith \& Watson, 2001:187). In a sense, all autobiography is autography, or fictional narrative interwoven with self-reference. When Coetzee, speaking at York University in 2006, was asked whether Boyhood was memoir or fiction, he responded, "Do I have to choose?" (Baker, 2006). As Sodonie Smith and Julia Watson (2001:36) note regarding Boyhood:

Coetzee explores identity vectors as multiply constructed ... While boyhood was a fixed time in his life, it was also a time that the narrator reads retrospectively as both facilitating tryouts of possible identities and undermining their realizations in the repressive apartheid state.

"Identity vectors", of course, keep on shifting and changing throughout the course of a life. Further, this process is not inevitably connected to socio-political conditions - at least, not in any straightforward way. For instance, Jacques Derrida in an interview with Derek 
Attridge in Acts of literature, tells of a level of need for what did not exist linked to the story-telling impulse of autobiography:

... the unique event [of the past] whose trace one would like to keep alive is also the very desire that what does not happen should happen, and is thus a 'story' in which the event already crosses within itself the archive of the 'real' and the archive of 'fiction' (Derrida, 1992:35).

George Gusdorf, one of the pioneers of autobiographical criticism, gives an example of the two-way traffic involved in this crossing of archives. It is the same sort of two-way traffic as that which informs Coetzee's "fictioneering" in, for instance Summertime. 4 Gusdorf tells how Lamartine wrote about a non-existent but suggestive vine that grew on his childhood house; an actual vine was subsequently planted and attached to that same house by Madame Lamartine (Gusdorf, 1980:43). Regarding Coetzee's own thoughts on fictioneering in Summertime, Mr Vincent, the interviewer, explains to Mme Denoël, Sophie:

... I have been through the letters and diaries. What Coetzee writes there cannot be trusted, not as a factual record - not because he was a liar but because he was a fictioneer. In his letters he is making up a fiction of himself for his correspondents; in his diaries he is doing much the same for his own eyes, or perhaps for posterity. As documents they are valuable, of course; but if you want the truth you have to go behind the fictions they elaborate and hear from people who knew him directly, in the flesh. (Coetzee, 2009:225-226.)

Of course, while supposedly presenting this "truth", Summertime is disallowing it, as Sophie in fact implies when she points out that we are all fictioneers (Coetzee, 2009:226). The "truth" regarding the author in the end is his entire oeuvre. It is this textual body which provides what Susan Barton in Foe calls "the substance of the truth" of a life (Coetzee, 1986:51).

Rupert Wood notes of Beckett's analysis of the Proustian aesthetic (one shared by Beckett himself), that the Proustian individual is

... afflicted by time, for in effect the 'individual' is nothing but a series of individuals. Thus, Beckett states, the desire of an

4 Coetzee, for instance, has "John Coetzee" present Julia with a proof copy of Dusklands (Coetzee, 2009:55). 
individual at time $A$ cannot be satisfied at time $B$, for the individual at time $B$ will no longer be the same individual. (Wood, 1994:4.)

Perceptions from different times and places are nevertheless ordered according to habit (related to oppressive Schopenhauerian "will"), to create a complacent sense of selfhood, and this tyrannical habit can only be eluded through access to the spaces opened up by "involuntary memory". Wood (1994:7) claims that the problems associated with this insight remained with Beckett throughout his life. Coetzee's fictioneering wants to suggest access to the same space (where "truth" regarding selfhood resides), albeit through what is presented as voluntary memory, governed by the habitual, but which is wrenched out of the habitual through its relation to fiction.

There is a psychological dimension to the need to write autobiography that is pertinent to the case that I wish to present in this essay. It must be borne in mind, however, that individual psychological imperatives parallel literary-historical ones. Andrew Bennett notes the post-Romantic reaction to the novel's romantic emphasis on the phenomenon, so to speak, of the "author".

Challenging the idea of authorship as authoritative and controlling are those views of the individual or the 'subject' as precisely lacking in agency, as controlled by ideology, as split or divided by the unconscious, and even as subject to, or the subject of, language itself. Indeed, we might conclude that the question of this authorial conflict of agency and its absence, deterioration, or eradication is a major part of our fascination with literary texts. (Bennett, 2005:8.)

This general statement holds true with regard to Coetzee's specific engagement with Beckett in the essay "The comedy of point of view in Beckett's Murphy" (Coetzee, 1992c). This essay stems from Coetzee's thesis, "The English fiction of Samuel Beckett: an essay in stylistic analysis", written at the University of Texas for the Ph.D. he obtained in 1969.5 His textual engagement with Beckett, to do with stylistic interpretation and critical understanding, is, therefore, not unrelated to what Foucault calls the "author-function", which includes "representations of the self and autobiography" (cf. Bennett, 2005:4-5). According to Coetzee, confession - an aspect of auto-

5 I have not been able to access this thesis in researching for the current essay, but the essay in question, along with the discussions in Doubling the point, apparently represent the core concerns of the thesis. 
biography - is intimately involved with the need to arrive at essential truth about the self (Coetzee, 1992a:252). His brief piece on Beckett appears to link with the confessional aspects of Boyhood (1997), Youth (2002), and Summertime (2009). Walter Rankin, commenting on Foe and the unsettling of any straightforward connection between factual report and fiction, states: "Coetzee's rendition places as its central motif the process of writing one's story, of placing the self within a text of one's own creation while attempting to express the truth of oneself." (Rankin, 1999:314.) Coetzee's autography, his fictioneering, however, is always so masterful that we can surely apply Foucault's (1984:102) observation to it.

Writing unfolds like a game that inevitably moves beyond its own needs and finally leaves them behind. Thus the essential basis of this writing is ... primarily concerned with creating an opening where the writing subject endlessly disappears.

Thus, the writing itself takes over. The "writing subject" is "banished" by the "written object" (Rankin, 1999:307). What is important in the case of the present essay is that this Foucauldian paradox is momentarily suspended in Coetzee's observations on the imaginary Beckett. This is a suspension which amounts to an example of fictioneering written from the standpoint of the actual, public Coetzee's framing narrative. Perhaps, given this condition, the writing subject will briefly emerge from the text long enough to shed light on why fictioneered Coetzee would not have written a Ph.D. thesis on fictioneered Beckett.

\section{Alternative Beckett, alternative Coetzee}

By the time the alternative South African Beckett started to work at the University of Cape Town in 1938, he had published a book on Proust, More pricks than kicks, and a volume of poems. His prose style at this stage, if not exactly established, was securely Beckettian, as Pilling (1994:17) notes, and was thus well on the way to becoming what the young Coetzee would want to imbibe. However, as already indicated, the alternative Beckett later wrote mutatis mutandis what the actual Beckett wrote, at a time when both Coetzees were particularly receptive to his influence. Thus, the problem concerning the alternative Coetzee's not wanting to write the Beckett Ph.D., becomes more intriguing. Coetzee stated in an early 1990s interview, in the collection Doubling the point, (Coetzee, 1992c), that his scholarly work on Beckett of the 1960s and 1970s was a means 
to express his "sensuous delight" in Beckett's style (Coetzee, 1992b:20). ${ }^{6}$ By 2006, Coetzee could feel that the force of his scholarly interest in Beckett might be put to one side, and, indeed, would have been put to one side had Beckett come to South Africa. This is not the case regarding the influence of his prose style. Intellectual engagement is displaced; creative engagement is secured. The partitioning of human functions, which shadows a Cartesian split in my view (between rarefied conceptualisation and substantial creative production), would seem to reflect an embedded trait in Coetzee, and is presented most fundamentally as such in Summertime, where Adriana Nascimento pronounces on "John Coetzee":

This man was disembodied. He was divorced from his body. To him, the body was like one of those wooden puppets that you move with strings. You pull this string and the left arm moves, you pull that string and the right leg moves. (Coetzee, 2009: 198. $)^{7}$

A character pronounces on an author, indeed, but in the truth-revealing mode of confessional fictioneering.

As Beckett did not come to South Africa, the rupture between Coetzee's scholarly and authorial relations with him was not effected, and yet the assurance behind the speculation remains for us to ponder. Coetzee has ever known himself remarkably well, despite certain qualified protestations to the contrary - which prove the point all the more clearly. ${ }^{8}$ What is it about Coetzee's alternative Beckett that he should have this effect?

$6 \quad$ In Homage Coetzee (1993:5) states that as a young man "[o]ne is more acutely sensitive and receptive to rhythms, tones, melodies, including the rhythms and tones of language, than at any time before or after". Though Coetzee claims in the Dagens Nyheter interview that Homage, being "fairly hastily written", will not "bear close interrogation" (Coetzee, 2003), it seems clear that Beckett's pre1952 work therein mentioned had an intensely pleasurable physical effect on him, relating to the "delight" mentioned earlier. As Rita Barnard (2007:16) reminds us: in Youth when John reads Beckett's Watt he "finds himself rolling on the floor with laughter".

7 This is a parodic parallel in Beckett fashion. As Coetzee (2007b:172) writes, Beckett's works can be seen as a "series of sustained raids on Descartes and the philosophy of the subject that Descartes founded".

Coetzee (1992b:105) states:

Whatever the truth [concerning Girard's influence on my writing], I feel that questions of influence on my novel-writing are not for me to answer: they entail a variety of self-awareness that does me no good 


\section{Beckett and Coetzee: style}

Let us consider how both writers achieve their desired styles. I believe this has to do with what one might call the decorum of the proper writerly perspective. Coetzee crafts his style through the assumption of a narrator with a cool intellect who maintains the coolness however awful the circumstances in order to carefully map experience through linguistic and compositional precision. (This coolness, though, might well hold in check a deep pain and compassion, which Coetzee does not see proper to indulge in in his writings.) Beckett achieves perspective and the fundamentals of his style by means of linguistic estrangement, famously obtained in the area of composition through his use of French, but also through mechanical manipulations of sequence, which, in the maddening repetition involved in all the possible permutations of various elements, as in Watt, disallow otherwise habitually used words to be absorbed in any complacent way. Both approaches are related to Coetzee's notion of "thrift", which he had long since perceived in Beckett (Coetzee, 1992b:20). Thrift for the two writers involves a stripping away of unthinking and habitual encumbrances, rhetorical, figural, conceptual - and not necessarily in the cause of brevity. Watt, for me, despite its substantial length, is a minimalist work because of its thrifty use of limited elements of setting, character and language. Coetzee's relation to thrift is that what is imagined usually clarifies and strips experience to reveal it in all its quiddity and haecceity. ${ }^{9}$ Like Beckett, he is deeply distrustful of the unthinking utterance, of language taken for granted. Some might feel the result to be emotionally austere, but Coetzee would claim that the author should not wear his heart on his sleeve, that clarity combined with what Marina Warner (2008:15) calls a "pitch-perfect lexicon" (in an essay on Beckett and Mallarmé), conveys far more than any amount of jaded or manipulative rhetoric. Thus, when he imagines Beckett's South African life, and dispassionately jettisons the young Coetzee's scho-

as a storyteller ... (You catch me, of course, in self-contradiction. If I don't want to look into myself, claiming that it isn't good for my novel writing, what am I doing conducting this interview ... ?). Foucauldian terms, applies "thrift" to the writer as opposed to the work: "the author is 'a certain functional principle by which, in our culture, one limits, excludes, and chooses' ... Foucault argues that we use him or her ... [as] 'the principle of thrift in the proliferation of meaning". When it comes to "autography" there is a congruency, as the author is also the subject (Rankin, 1999:307). Coetzee, thus, doubly underlines this "principle of thrift in the proliferation of meaning" attached to the author by fictioneering with regard to himself. 
larly interest in Beckett in a moment of retrospective self-knowledge, perhaps in the wake of Boyhood and Youth, we anticipate the clarity of revelation. What does the moment reveal? An unexplained, even inexplicable response in relation to any information we might be given: had Beckett come to South Africa, Coetzee wouldn't have written his Ph.D. on him. In other words, anticipated revelation is displaced by apparent concealment. Reason fails us and so we begin to suspect the presence of a predictable enough emotional knot in Coetzee's imagined relation with the alternative Beckett; predictable because Coetzee (2006:75) himself has introduced the subject of a spiritual father in the imaginary history, and also because the father is generally a problematic figure in Coetzee's obliquely autobiographical writing. 10

\section{The outsider}

As already pointed out, Beckett's style gave Coetzee a sensuous pleasure, a delight. Working on Beckett in a scholarly way was, he says, a means for him to express this delight. Again, why would this not have been so in the case of the alternative Beckett? Coetzee claims he was attracted to Ford Maddox Ford, because of Ezra Pound's praise of his style (Coetzee, 1992b:20), but, in a thoughtprovoking conflation, he was also attracted to Ford because of the fact that he was an "outsider", a position with which Coetzee clearly empathises. 11 In moving to, for Coetzee, the all too familiar realm of the Western Cape of South Africa, would Beckett have become a type of insider, despite the delight his style gave, and so less at-

Consider the conclusion of Summertime, where "John Coetzee", faced with the prospect of having to nurse his ailing father, writes in an "Undated fragment":

\footnotetext{
Alternatively, if he will not be a nurse, he must announce to his father: I cannot face the prospect of ministering to you day and night. I am going to abandon you. Goodbye. One or the other: there is no third way. (Coetzee, 2009:266.)
}

This albeit tortured realisation, in the context of fictioneering, is a stage in what Rosemary Jolly, writing of Susan Barton's relation to Foe, calls "the male authorial fantasy of self-engenderment" (Coetzee, 1996:140). The male author must turn aside from real fathers and spiritual fathers to become his own selfengendered texts.

11 Margot's narrative in Summertime is just one example in the book which underlines "John Coetzee's" alienness:

John's presence on the farm is a source of unease. After years spent overseas - so many years it was concluded he was gone for good he has suddenly reappeared among them under some cloud or other, some disgrace. (Coetzee, 2009:89.) 
tractive as a research topic? Seen in these terms, Coetzee's split between scholarly work and stylistic influence again evokes the Cartesian one considered above, between reason and organic existence in its guise of intuitive absorption, creative influence. The professor of the creative writing class belonged in the latter realm and could not be brought into the realm of reason and intellectual endeavour.

Was Beckett, like Ford, initially an outsider in Coetzee's eyes? Although he was first attracted to him through Watt, Coetzee knew that Beckett really found his style once he started to write in French (Coetzee, 2007b:169).12 Let me briefly consider the parallel between Beckett's use of French and the character JC's relationship with English in Diary of a bad year (Coetzee, 2007a). JC, a slightly blurred double of Coetzee himself, representing a metatextual extension, perhaps, of the autobiographical impulse found in Boyhood and Youth, tells of the strangeness of English, how it does not seem to be a mother tongue, but is rather a tongue that he has had to master (Coetzee, 2007a:197). Perhaps language is inherently strange (as JC puts it, perhaps every language is a "foreign language" Coetzee, 2007a:197), or one needs always to sense its strangeness - be an outsider to it - in order to be a writer like Beckett or JC.

Marina Warner (2008:16) introduces a relevant passage from Ovid's Metamorphoses concerning the inherent strangeness of utterances.

After the goddess Leto has given birth to the divine twins, Apollo and Diana, she goes to bathe in a pond but is driven away by men cutting rushes by the shore. In revenge she turns them into frogs. Ovid mimics alliteratively the subhuman noises the men make after the metamorphosis takes hold of their human bodies and deprives them of human speech: 'quamuis sint sub aqua, sub aqua maledicere temptant' (however much they lie under water, they struggle to curse underwater).

The close repetition of "qua" in "quamuis" and "aqua", mimics the croaking of frogs and inspires, according to Warner (2008), Lucky's "vociferation" at the end of Act One of Godot: "quaqua".13 In Sum-

12 In the Dagens Nyheter interview with Attwell, Coetzee (2003) notes that it was Beckett's pre-1952 work that attracted him most.

13 This vociferation is also used by Beckett in How it is. In More pricks than kicks the character Belacqua's name, taken from one of the damned in the Purgatorio, encompasses the same sound. Belacqua is famous for his appalled 
mertime, when asked by Margot for a story to help the two of them pass the time in the broken-down Datsun pickup, John includes this very vociferation: "Quaquaquaqua" (Coetzee, 2009:113). The frog theme from Ovid and Beckett also ties in with an earlier section of Summertime, when, according to Julia, the woman being interviewed at that point, John is "not a prince but a frog"; an affirmation of his outsider status, as she concludes: "Because he was not human. Not fully human." (Coetzee, 2009:83.) If, as Warner says, vociferations are "close to the springs of language", they are related to the "closed-class" and "syntacticon" of which Ann Banfield writes. According to Banfield, Beckett relies a great deal on grammatical function words, like determiners and pronouns, considered "closedclass", along with "semi-lexical" categories of words, such as prepositions, which form an intermediate class between lexical and functional categories. Such words belong to what linguists call the "syntacticon". Overemphasis on such function words (at the expense of nouns and verbs) contributes to the "making strange" of language (Banfield, 2003:17).

\section{Influence}

But what about the matter of influence? What if both Coetzees are influenced by the prose style of both Becketts? Beckett's deliberate courting of the unfamiliar that helps define his style is absorbed by Coetzee. In other words, Beckett's use of defamiliarisation becomes part of Coetzee's realm of the linguistically familiar. Coetzee himself, however, an English speaker from an Afrikaans background, is very aware of linguistic defamiliarisation; and so can bring to what he has, as it were, domesticated of Beckett's, his own sense of the inherent foreignness of language. In the Margot section of Summertime, Coetzee's English narrative veils an Afrikaans world, and even the vanished Khoi world, which now only exists in the place names of the Karoo and the scraps of Khoi John has learned. Thus, Afrikaans and Khoi words are refracted through the English surface of Summertime, though John translates the former and Mr Vincent (somewhat pat, as if at the behest of a publisher) translates the latter. Despite these translations, one senses the continual presence of the African languages and, surely, their strangeness for an international readership (a sense buttressed by the overwhelming other-

response regarding the suffering of lobsters boiled alive in the story "Dante and the lobster". He hopes it's a quick death; the (unspecified) narrator responds: "It is not" (Beckett, 1970:21). The implications in a discussion of Coetzee are large, but tangential to the present work. 
ness of the Karoo).14 The same sense is apparent in In the heart of the country (Coetzee, 1978), perhaps Coetzee's most obviously constructed novel. Its numbered paragraphs are not unrelated, it may be, to Beckett's permutations (as in Watt), where words are arranged according to the formal possibilities of material sequences (Beckett, 2006:239-240). The effect of the combined elements in this novel - English and Afrikaans inhabiting the same linguistic space in an obviously artificial manner; numbered paragraphs; the strangely graceful consciousness of a spinster who contemplates the most terrible axe-murder - the effect of these elements is to prompt that incipient motion-sickness associated with ontological defamiliarisation. 15

What is thus embodied in this novel, is discussed theoretically in the Diary of a bad year. Theoretical discussion is partly the mode of the Diary. It must not be thought that Coetzee is merely therein discussing defamiliarisation, he is neatly side-stepping actual engagement with it. The book's tripartite page layout, a division among formal disquisition and the subjective thoughts and experiences of two characters, is estranging in its own way. Static formal disquisition modulates, as the novel unfolds, into active participation. For instance, the first disquisition in the novel, on Hobbesian state control, bleeds into the narrative sections to become the insidious control that the character Anya's awful boyfriend, Alan, has over JC when he accesses the details of JC's personal life through a device hidden in the latter's computer. Watergate and Orwell are surely in

14 The otherness is not conveyed through description, but through personal responses to it. Speaking with Margot, John recalls Eugène Marais's description of an old male baboon's melancholy at sunset, and "understands" what he was thinking:

Never again, he was thinking: Just one life and then never again. Never, never, never. That is what the Karoo does to me too. It fills me with melancholy. It spoils me for life ... It wrenched my heart when I was a child, and I have never been right since. (Coetzee, 2009:97.)

Warner (2008:14) writes of Beckett's use of French, for instance:

The translation into a foreign language helps estrange the characters and their setting - strands them somewhere else, somewhere their speech and their own labels do not match exactly.

She goes on to write that, "[t]he physicality of a word grows lighter and less substantial when we know what it means without having to think" (Warner, 2008:14). Being prompted to think about them makes words heavier and more substantial. The point holds good for Beckett's manipulation of structures and permutations. 
the background, as well as more contemporary, digital, manifestations of invasions of privacy (Coetzee, 2007a:4, 115). And so the distinction between subjective experience and objective perception is blurred, along with the distinction between reasoned disquisition and created work. It is at least worthy to note that this blurring should occur in a novel about an alternative Coetzee written by the actual Coetzee - and written at a time when the latter had also been writing (on a much smaller scale) about an alternative Beckett.

\section{Coetzee's early scholarly work on Beckett}

Coetzee's early work on Beckett involves a highly structured, semiscientific approach to the subject, with Coetzee choosing random samples from Murphy, for example, by means of a computer programme and subjecting these samples to careful linguistic analysis. $\mathrm{He}$ did so in order to examine what he calls the "antigrammar of point of view" in the novel (Coetzee, 1992c:36). This deliberately subversive use of grammar is illustrated, for example by the difficulty of establishing the originators of certain perceptions and formulations in the text. We are sometimes at a loss to know who is speaking: is it the author, the narrator, a character, or the alter ego of a character? Or is it a deeper impersonal structure (an X figure, as in transformational grammar) that is being deployed?16 For instance, Coetzee examines the expression "... and Murphy was well advised to abandon hope for the day ...". He notes the different effect in the slightly changed expression, "Murphy would have been well advised to abandon hope for the day ...", which involves a structural $X$ as easily removed by the conditional construction as it is posited, once the statement has been made, whereas in the first case we wonder who did advise him, as, from a realist point of view, no-one could have. Thus, we are being made conscious of Murphy's author's working presence, of his deliberate announcement of his presence (Coetzee, 1992c:33). This "being made conscious" ties in with Coetzee's rather predictable (at least in retrospect) 1970s-type point about the deliberate foregrounding of authorial presence. It also obviously ties in with the idea of the constructed nature of fiction, and by extension all writing, but it leads to an important ob-

16 The problem is intensified later in Beckett's career, as Simon Critchley (1998:115) observes:

The dramatic tension of the Trilogy, to my mind, is found in the disjunction that opens up between the time of narrative, the chain of increasingly untellable and untenable stories, and the nonnarratable time of the narrative voice. 
servation, certainly in the light of this essay. If the author's presence is so apparent in fiction, why not also fictionalise the author? In another example, Coetzee is not convincing, because he invests too much in his rigidly objective approach to Beckett. Coetzee looks at the permutations involved in Murphy's consumption of his biscuits, from Ginger to anonymous, and deems his sense that the anonymous biscuit is "very likely the least palatable" (Beckett, 2006:59), a well-considered divorcing of language from reality. "There is no way of reconciling grammar with reality here", says Coetzee (1992c:34). Had he permitted himself to examine the passage in a slightly extended context not determined by a computer's arbitrary decree, he would have needed to accommodate the fact that, although Murphy does feel that the anonymous biscuit is "very likely the least palatable", he has eaten many. A few lines further he acknowledges that this illogical notion is, in his words, a "prejudice" (Coetzee, 2006:60), which might be conquered. The prejudice always dominates Murphy's consciousness. Thus, in accordance with the exclusionary nature of prejudices, he cannot truly taste the biscuit. Hence the impossible qualification after the event, "very likely", is not at odds with reality - Murphy's psychological reality. Can we make anything of Coetzee's rather rigid approach to this example? Let me return to this matter at the end of my article.

\section{Defamiliarisation}

The distinctions in narrative point of view for Coetzee are not important in themselves. He is concerned with their destabilising effect. It is noteworthy that it is Beckett who initially exemplifies the production of these distinctions for Coetzee and who brings us back to the observation: if the author's presence is so apparent in fiction, why not also fictionalise the author? The writing of fiction, in other words, seamlessly incorporates what Coetzee must consciously posit in his imaginary history of the South African Beckett. The Beckett we find in work stemming from Coetzee's Ph.D. (a Beckett whose name Coetzee presents in the Murphy essay with and without inverted commas to indicate the distinctions), thus anticipates the alternative Beckett of the imaginary history, the alternative Coetzee of the same, and also, as discussed, the doubled Coetzee, very explicitly present in Diary of a bad year. In the novel the JC figure (who at one point ponders a photographic image of the actual Beckett, in relation, interestingly, to thoughts on the imposition of the photographer's will on his subject (Coetzee, 2007a:201)) can diverge from the actual Coetzee in the same way, though to a much greater degree, as in the imaginary history. The splitting of selves highlights 
autobiographical and biographical elements at the same time as it links these to the creation of fiction. Thus, the self's continuity with the least objectively determined elements of the linguistic construct is dramatised.

The blind force of the will, axiomatically manifest in the linguistic construct, provokes the need for defamiliarisation. Coetzee perceives that Beckett's writing, through defamiliarisation, absorbs the force of the will within language. The will in such cases is at one with what might be perceived as the autonomous workshop of the language itself, and is not an imposition from without or an uncontrolable force from within. Coetzee is apparantly more of a structuralist in orientation regarding linguistic usage, than Beckett, whose compulsion to decentre "will" is rather in sympathy with, say, Schopenhauer than with Chomsky. It is perhaps more fair (though no less simplistic) to say that if both writers are very aware of their language and the existential and linguistic implications attending its usage, Beckett favours the existential, Coetzee the linguistic. But Coetzee, for all his rational presence in his writing, has an elegance of style and gift of narration that transcend the prescriptions of his rationalism, or may even be a function of, on a higher level, that very rationalism. There is a fluency in the authorial Coetzee which combines with accessibility, a popular type of accessibility not present in Beckett (which is not to say that Beckett cannot be popularly accessible). On the other hand, Coetzee's style achieves nothing like the density attending Beckett's; a density, I believe, not premised on the type of cool-headed control we find in every word in Coetzee, but on almost the opposite: an identification of the writerly self with what l've called above the workshop of language, and this as mediated through satirical consciousness which is almost unhinged; or, is mediated much of the time through tragic consciousness paradoxically saturated with a sense of humour.

The distinction is fictioneered by Coetzee in Summertime, when Mme Denoël, Sophie, compares "Coetzee" with an unspecified "giant" writer.

In general I would say that his work lacks ambition. The control of the elements is too tight. Nowhere do you get a feeling of a writer deforming his medium in order to say what has never been said before, which is to me the mark of great writing. Too cool, too neat, I would say. Too easy. Too lacking in passion. (Coetzee, 2009:242.) 
Again, this is a dubious source, a character from one of Coetzee's own works. Yet the fictional pronouncement, though qualified by a character's personal (French) perspective, bears the substance of a truth in relation to the distinction between the experimental modernist, Beckett, and Coetzee, the restrained metafictional perfectionist. 17

\section{Conclusion: the anonymous biscuit}

I return briefly and finally to Murphy's anonymous biscuit. Coetzee's scholarly engagement with Beckett emphasises reason, control, computation and objectivity, and these sometimes tie in with Beckettian strategies such as permutation for the sake of exhausting semantic and material possibility. However, if delight is at the basis of Coetzee's careful examining, it is hard not to think that the delight lies not in the Ph.D. aspect of his work on the level of reason as he claims, but at a deeper level where reason is initially engaged only to let other forces take over (the rhythms and tones of language, humour and the satisfaction of thrift). Thus, Coetzee's deliberate avoidance of anything other than an underlying model of linguistic rationalism at work in the example of the anonymous biscuit is a type of patriarchal repression linked to the spiritual father syndrome in himself, which is only finally acknowledged, implicitly acknowledged it is true, but not concealed as earlier speculated, when the alternative Coetzee faces the alternative Beckett, and refuses to engage his reason, while opening his talent to his influence.

\section{List of references}

ATTRIDGE, D. 2005. J.M. Coetzee and the ethics of reading. Pietermaritzburg: University of KwaZulu-Natal Press.

ATTWELL, D. 2008. Coetzee's estrangement. Novel, 41(2 \& 3):229-243.

BAKER, J. 2006. J.M. Coetzee in York. http://johnbakersblog.co.uk/jm-Coetzeein-york/ Date of access: 2 Apr. 2010.

BANFIELD, A. 2003. Beckett's tattered syntax. Representations, 84:6-29.

BARNARD, R. 2007. Apartheid and beyond: South African writing and the politics of place. New York: Oxford University Press.

BECKETT, S. 1970. More pricks than kicks. London: Picador.

17 Attridge, speaking to Derrida, reminds him that he once said of Beckett, that his texts "make the limits of our language tremble" (Derrida, 1992:60). In his book on Coetzee, Attridge characterises Coetzee's work as following on from that of Kafka and Beckett, demonstrating what might be classified as "late modernism" or "neomodernism" (Attridge, 2005:2). However, Attridge would not claim that Coetzee makes the limits of our language tremble. 
BECKETT, S. 2006. Novels. Vol.1. Ed. by P. Auster. New York: Grove.

BENNETT, A. 2005. The author. New York: Routledge.

COETZEE, J.M. 1978. In the heart of the country. Johannesburg: Ravan.

COETZEE, J.M. 1986. Foe. London: Secker \& Warburg.

COETZEE, J.M. 1992a. Confession and double thoughts: Tolstoy, Rousseau, Dostoevsky. (In Attwell, D., ed. Doubling the point: essays and interviews. Cape Town: David Philip. p. 251-293.)

COETZEE, J.M. 1992b. Interviews. (In Attwell, D., ed. Doubling the point: essays and interviews. Cape Town: David Philip. p. 17-30; 103-106.)

COETZEE, J.M. 1992c. The comedy of the point of view in Beckett's Murphy. (In Attwell, D., ed. Doubling the point: essays and interviews. Cape Town: David Philip. p. 31-38.)

COETZEE, J.M. 1993. Homage. Threepenny review, 53:5-7.

COETZEE, J.M. 1997. Boyhood. New York: Putnam.

COETZEE, J.M. 2002. Youth. London: Secker \& Warburg.

COETZEE, J.M. 2003. Dagens Nyheter interview with David Attwell. http://www.dn.se/kultur-noje/an-exclusive-interview-with-j-m-Coetzee1.227254 Date of access: 2 Apr. 2010.

COETZEE, J.M. 2006. Samuel Beckett in Cape Town: an imaginary history. (In Knowlson, J. \& Knowlson, E., eds. Beckett remembering: remembering Beckett. London: Bloomsbury. p. 74-77.)

COETZEE, J.M. 2007a. Diary of a bad year. London: Secker.

COETZEE, J.M. 2007b. Inner workings: essays 2000-2005. London: Secker.

COETZEE, J.M. 2009. Summertime. London: Secker.

CRITCHLEY, S. 1998. Who speaks in the work of Samuel Beckett? Yale French studies, 93:114-130.

DERRIDA, J. 1992. Acts of literature. Ed. by D. Attridge. New York: Routledge.

FOUCAULT, M. 1984. What is an author? (In Rabinow, P., ed. The Foucault reader. New York: Pantheon. p. 101-120.)

GUSDORF, G. 1980. Conditions and limits of autobiography. (In Olney, J., ed. Autobiography: essays theoretical and critical. Princeton: Princeton University Press. p. 28-48.)

JOLLY, R.J. 1996. Colonization, violence, and narration in white South African writing: Andre Brink, Breyten Breytenbach, and J.M. Coetzee. Athens: Ohio University Press.

KERMODE, F. 2009. Fictioneering: review of Summertime by J.M. Coetzee. London review of books, 31(19):9-10.

KNOWLSON, J. 1995. Damned to fame: the life of Samuel Beckett. London: Bloomsbury.

PILLING, J. 1994. Beckett's English fiction. (In Pilling, J., ed. The Cambridge companion to Beckett. Cambridge: Cambridge University Press. p. 17-42.)

RANKIN, W.P. 1999. Autobiographical fiction vs. fictional autobiography: Christa Wolf's Kindheitsmuster and J.M. Coetzee's Foe. Comparative literature studies, 36(4):306-319.

SMITH, S. \& WATSON, J. 2001. Reading autobiography: a guide for interpreting life narratives. Minneapolis: University of Minnesota Press.

WARNER, M. 2008. Who can shave an egg? Times literary supplement, 5474:14-17, Feb. 29.

WOOD, R. 1994. Beckett as essayist. (In Pilling, J., ed. The Cambridge companion to Beckett. Cambridge: Cambridge University Press. p. 1-16.) 


\section{Key concepts:}

antigrammar

autobiography

Beckett, Samuel

biography

Coetzee, J.M.

defamiliarisation

metafiction

ontological doubt

Kernbegrippe:

antigrammatika

Beckett, Samuel

biografie

Coetzee, J.M.

metafiksie

ontologiese twyfel

outobiografie

vervreemding 
